\title{
The transport challenge in the sustainability of megacities
}

\author{
A. Igwe \\ Department of Geography, Royal Holloway, University of London, UK
}

\begin{abstract}
The United Nation defines Megacities as cities with ten million or more inhabitants. Megacities now occupy a prominent place in the global sustainable development debate. They pose a major development challenge contributing immensely to global warming, environmental pollution and poor urban life quality. Megacities are increasing in number, size and geographical spread and are moving well beyond the ten million mark. By 2015, the top three megacities, Tokyo, Mumbai and Lagos, are each expected to have exceeded 20 million inhabitants.

The place of transport in megacity sustainability is crucial. Transport has emerged as one of the major challenges governments have to contend with in their struggle for sustainable development, and policy makers the world over are beginning to appreciate the need to address the motorization and mobility crisis.

This paper examines the transport challenges confronting sustainable development in Tokyo, Mumbai, Lagos and New York. It considers city profiles, congestion and pollution levels, and the imbalance in transport planning and policies and recommends a positive reconstruction of transport system to meet societal expectations. While Tokyo, Mumbai and Lagos will be the top three, mirroring a decade ahead, the significance of New York is that it was the first to attain megacity status. The problem of scale is central to the arguments and megacities are found to be greatly responsible for global warming and dragging productivity beyond national boundaries.

It is the author's view that transportation planning and management for megacities will require a paradigm shift if sustainability is going to be achieved. To meet these challenges, Megacities will need transport models that best fit their socio-economic development goals, geographic constraints, together with sound transport economic policies and social education.

Keywords: sustainability, megacities and transport challenge.
\end{abstract}




\section{Introduction}

Megacities are a common feature of our rapidly urbanizing world. There are various definitions for the megacity but all are population based. The most widely used, however, is that of the United Nations which puts the figure at 10 million or more inhabitants. That in itself presents a new problem of delimitation and delineation as we see cities growing in multiples of ten million. Needless to say that there is not yet an established definition for the megacity and the author accepts that the next step forward will be in the direction of standardizing the definition. Be that as it may, this paper proceeds with the most prevailing definition in order to establish the challenges that arise due to escalating city sizes.

Sustainable transport is a transport system that continuously meets the demand for transport in a balanced variety of modes, efficiently and in a friendly environment.

The arguments in this paper are primarily focused on selected megacities namely Tokyo (Japan), New York (USA), Mumbai (India) and Lagos (Nigeria). The significance of these cities is that within the next decade, Tokyo, Mumbai and Lagos will be the top three while New York has a beautiful history as the first to attain megacity status. By 2015, barely a decade away, Tokyo, Mumbai and Lagos will each have projected populations of 26.4 million, 26.1 million, and 23.2 million respectively (UNCHS [10]). Interestingly, these are all coastal cities which characteristically have wider transportation alternatives but also greater challenges.

Traditionally, megacities have been located on coastlines due largely to trade and transport access, food and other ecological advantages. Capital inflow through the ports makes coastal cities of high economic value to national and global economies. This explains in part the phenomenal population growth in Coastal cities. Little wonder then that eight of top ten megacities in the world are located by the Coast. These include:

\begin{tabular}{|l|l|l|l|}
\hline 1. Tokyo & Coastal & 6. Shanghai & Coastal \\
\hline 2. Mexico City & Inland & 7. Lagos & Coastal \\
\hline 3. Mumbai & Coastal & 8. Los Angeles & Coastal \\
\hline 4. Sao Paulo & Inland & 9. Calcutta & Coastal \\
\hline 5. New York & Coastal & 10.Buenos Aries & Coastal \\
\hline
\end{tabular}

It is estimated that about $44 \%$ of the world's population live within 150 kilometres of the coast. In the United States, around $53 \%$ of the population lives near the Coast and since 1970 there have been 2000 homes per day erected in Coastal areas (UN Atlas of the Oceans [22]).

\section{City profiles}

New York: New York City is presently the third largest coastal city in the world with a population of about 17 million and area of $516 \mathrm{~km}^{2}$. By 2015 its projected 
population will be 17.6 million resulting in population density of 34,075 Persons $/ \mathrm{km}^{2}$. New York has a civilian labour force of around 9.5 million as at December, 2005. It is a major center for business and commerce and is one of the four world cities (along with London, Paris, and Tokyo) controlling world finance. It is estimated that if New York were a nation it would have the 17 th largest economy in the world (Wikipedia [15]).

Tokyo: Tokyo, capital of Japan, is the world's largest and most sophisticated megacity. Its population is projected to remain 26.4 by 2015 . Tokyo's Bay is estimated at $1000 \mathrm{~km}^{2}$. It sits on an entire land area of $386.2 \mathrm{~km}^{2}$, giving a population density of 68,358 person $/ \mathrm{km}^{2}$. In 1995 , the number of employed people living and working in Tokyo came to 6.31 million, approximately $10 \%$ of the national total. Economically, Tokyo, with 800,000 private ventures as at 1995, constitutes one third of Japan's major industrial economy. It is an important wholesale centre, making transport a critical factor. The city's daytime working population is 8.77 million. Tokyo constitutes $12 \%$ of Japan's business establishments, and the seat of many large corporations (Tokyo Teleport [14]).

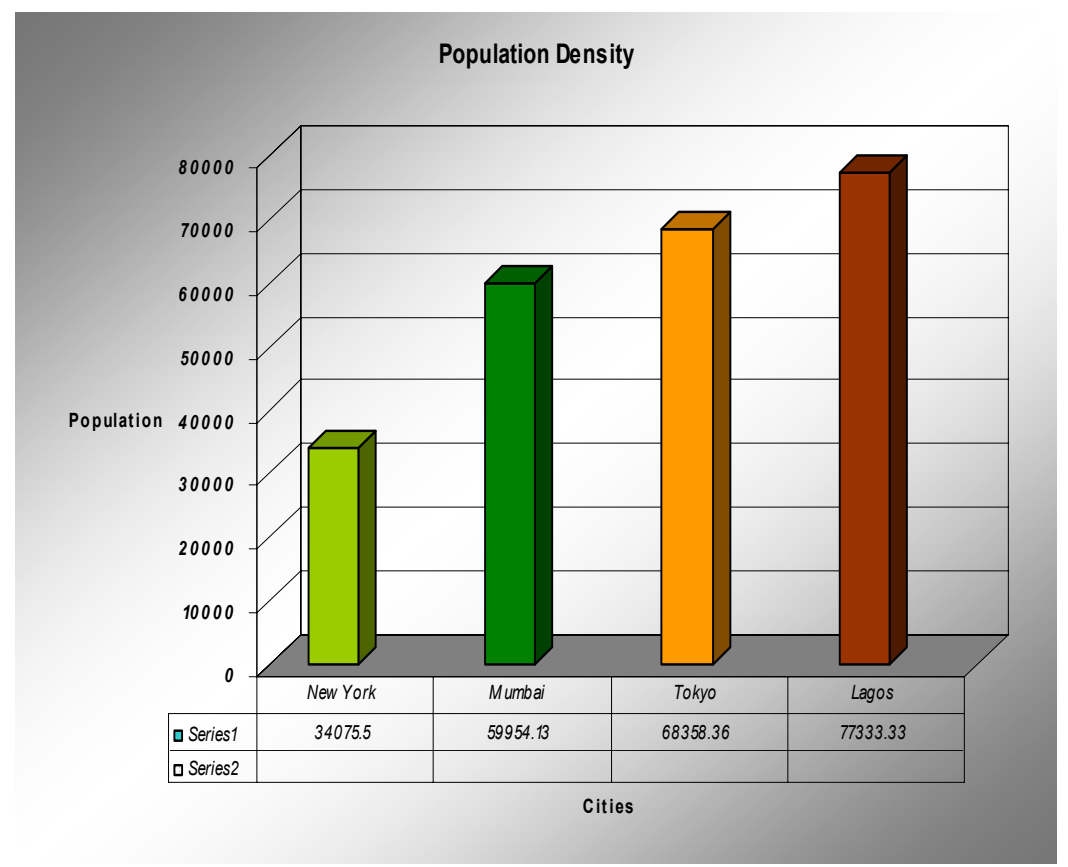

Figure 1: $\quad$ Population density graph of selected megacities (Source: Author).

Mumbai: Previously known as Bombay, Mumbai is now the second largest coastal city in the world and India's premier port with a metropolitan population of 20.94 million. Mumbai is an agglomeration of seven islands brought together through three centuries of reclamation. Its land area totals $436 \mathrm{~km}^{2}$. Its 
population is projected to reach 26.1 million by 2015 , making population density of 59,954 persons $/ \mathrm{km}^{2}$. It is the commercial capital of India, contributing $10 \%$ of factory employment, and some $40 \%$ of India's foreign trade. It is the home of most of India's research and technical industries (Dwivedi et al [4]).

Lagos: With its current 16.9 million inhabitants, Lagos is the fifth largest coastal city in the world. It was a mere 288,000 people in 1950 but today it is Africa's most populous city, on its way becoming the third largest city in the world. By 2015, Lagos with a projected population 23.2 million on an area of $300 \mathrm{~km}^{2}$ (only $0.03 \%$ of Nigeria's land area), will be having a population density of 77,333 persons $/ \mathrm{km}^{2}$. It is Nigeria's economic capital, housing over $50 \%$ of the country's financial and manufacturing sector as well as its major air and sea ports. It is estimated to employ over $20 \%$ of Nigeria's labour force (Rakodi [7]).

Reorganizing these data in population density hierarchy, the order becomes Lagos, Tokyo, Mumbai and New York and this gives us an idea of the value of space and a guide to appropriate transport land-use model.

\section{Do mega-cities have special transport problems?}

A look at New York reveals traffic congestion as a growing burden threatening the state's economic development. Congestion on New York's urban highways is growing as a result of increases in vehicle travel and population. In 2003, about $39 \%$ of urban arterials in the city were considered congested because they carry more traffic than they were designed to handle, causing significant rush hour delays. Growing urban traffic congestion also contributed to longer commute times in New York. The average daily one-way commute in New York increased from 28.6 minutes in 1990 to 31.7 minutes in 2000. This resulted in an additional 26 hours a year in traffic for an average New York commuter - an equivalent of three full working days relative to 1990. The U.S. General Accounting Office puts the country's annual cost of lost productivity due to traffic congestion at over $\$ 100$ billion (TRIP [9]).

Tokyo traffic congestion has been branded chronic, being associated with huge time and money loss to businesses and ordinary citizens. Japan's famous 'just-in-time' delivery system to manufacturing plants has promoted truck over rail traffic and this has lead to enormous traffic jams. Current estimates put the loss due to congestion at an average 3.8 billion person-hours in all of Japan [26]. Cutting traffic congestion is therefore a priority task for the city.

Mumbai records an average of 6 million passengers per day by rail and 4.5 million per day by bus. The average peak hour loading of trains (4,000 passengers per train) is more than double the design capacity of 1,800 per train and crush load capacity 2,600 per train. Buses also, are known to be excessively overcrowded, carrying $88 \%$ of the region's motorized personal trips (World Bank [16]). Vehicle population in Mumbai is approaching a million and there is a risk of a shift to private transport because of the inadequacy of public transportation. This will worsen the level of congestion which is already threatening the economy and environment. 
Lagos: According to Rakodi [7], the transport demand in metropolitan Lagos in 1990 hovered between 7 to 10 million passenger trips per day, of which over $95 \%$ were by road (mainly by car, bus, and taxi). As a result of an overdependence on road transport in Lagos a typical Lagos worker spends an average of 2.5 hours daily in journey to work traffic which has grave consequences on national productivity. It is customary for workers living in Lagos to wake up as early as $4 \mathrm{am}$ in order to accommodate traffic delays due to congestion. However, by 1997 the population of Lagos was just about 11 million and so we can rightly anticipate over 20 million passenger trips per day in a decade's time. This will definitely exert an enormous economic impact on this West African gateway city.

Looking at the environmental issues relating to energy consumption and associated pollution, we see $\mathrm{CO}_{2}$ emission from transport sources accounting for as much as $30 \%$ in Tokyo and $22 \%$ in Japan with $90 \%$ of these emissions being caused by the fuel consumption of automobile traffic. World Energy Outlook ((EIA [17]) shows that the transport sector is responsible for almost $60 \%$ of oil consumption in OECD countries and is likely to continue to be so for the next two decades. However, the report notes that the fastest growth will soon come from non-OECD countries which are projected to double their consumption within the next decade or so. Transport's contribution to environmental pollution is well documented. Even the UK (a world leader in reducing emissions) official statistics shows an $85 \%$ increase in pollutants from the airline industry and 59\% for freight transport since 1990 and, while overall emissions dropped 10\% between 1990 and 2002, the increase from the transport sector as a whole was $50 \%$ (The Guardian [18]).

Environmental Defence [19] estimates that $15 \%$ of the world's emissions of carbon dioxide, $50 \%$ of nitrogen oxide and $90 \%$ carbon monoxide are due to motor vehicles. Furthermore, the report states that a gallon of gasoline weighs 6 pounds, but when burned and combined with oxygen in the air, the resulting compound weighs nearly 20 pounds and argues that if fuel economy were improved by 5 m.p.g., American consumers would save 1.5 million barrels of oil per day, more than half of what it imports from the Middle East. In the light of the above, the sustainability of auto-oriented transportation systems is very questionable.

Also, the four cities in question exceed the world health standard of pollution in one way or the other due to transport emissions. The level of $\mathrm{NO}_{2}$ in New York, Tokyo and Lagos averages 79, 68 and $66 \mathrm{mg} \mathrm{m}^{3}$ respectively against $50 \mathrm{mg} \mathrm{m}^{3}$ standard. Mumbai is high on suspended particles with $240 \mathrm{mg} \mathrm{m}^{3}$ against the standard $90 \mathrm{mg} \mathrm{m}^{3}$ (World Bank [18]). Nitrogen Dioxide could be caused by geographic factors like coast, valley and aerobic decomposition but the major man-made cause is fossil fuel consumption. Motor vehicle traffic is a major source of air pollution in the megacities. In half of them, it is the single most important source. It is a major source of four of the six major air pollutants - carbon monoxide, nitrogen oxides, hydrocarbons and lead - and contributes to the particle matter concentration as well (WHO/UNEP [11]) 
Transportation is reported to account for 30\% of energy use in New York and $37 \%$ carbon dioxide emissions and by 2015 , energy use for transportation is forecasted to grow 9\%. Following current trends, the report believes that in the next two decades, daily travel may increase by 50\% (NYSERDA [6]). The sustainability of the environment and human settlements are increasingly threatened by the increasing use of private motor vehicles. Currently, transport accounts for $58 \%$ of global oil consumed, and $25 \%$ of primary energy use, of which road traffic accounts for some $72 \%$. With regard to emissions, the transport sector accounts for $22 \%$ of total $\mathrm{CO}_{2}$ emissions, some $66 \%$ of $\mathrm{CO}$, some $47 \%$ of nitrogen oxide, and $39 \%$ of hydrocarbons. Over $70 \%$ of these emissions come from the road sector (Global Policy Forum [20]).

Many studies have since confirmed that nitrogen, particulates, acidifying gases, heavy metals, and organic pollutants travel in the atmosphere for thousands of kilometres within and across national borders, interacting with each other and forming secondary pollutants before being deposited.

According to the WHO/UNEP study [11], the number of vehicles in the world is likely to double from the 1992 figure of 630 million vehicles within the next two to three decades. As cities expand into megacities, more people will drive more vehicles greater distances and for longer times. In the absence of controls, the automotive emissions will likewise increase.

In the State of the World report on coastal vulnerability, the US National Oceanic and Atmospheric Administration (NOAA) used large populations, high densities, and high growth rates in coastal areas as indicators of coastal vulnerability. These indicators are significant because they reflect potential population exposures to the effects of sea level rise associated with climate change (Worldwatch [21]).

From the above, it becomes pretty obvious that megacities do exhibit special transportation problems. They are characterized by enormous traffic congestion due to large population struggling over limited space, imbalance in modal distribution or transport planning, overdependence on motorized transport and associated pollution. These in turn lead to excessive road safety issues and huge economic loss due to traffic delays. The central issue here is that of scale and appropriate responses.

Furthermore, transport contributions to global warming have been documented. A report by Worldwatch Institute [21] shows that transportation is the world's fastest growing form of energy use accounting for nearly $30 \%$ of world energy use and $95 \%$ of global oil consumption. It affirms that even relatively small shifts in transport choices can have significant impacts.

Sustainability itself is rather a complex phenomenon requiring balancing alternative choices to achieve an optimal solution. Sustainable development has been defined as the ability to meet the needs of the present as well as the future. So, mirroring sustainable development objectives, we can infer that the present transport consumption pattern is far from sustainable and has the potential to wipe away a century's oil need in one decade. Whatever mode of transport (walking, cycling, motorization, rail transit, air transit or any combination), megacities will continue to experience comparatively higher rates of pollution, 
congestion, accidents, energy consumption, land use and environmental degradation. The associated costs of these will also be higher given the problem of scale. It is not the presence of these in the megacities that constitutes the challenge (as indeed they are characteristics of the megacities) but the establishing a continuum of the best balance of alternatives that meets sustainability challenges over time. Moreover, evidence abounds that Megacity problems are heightened by serious deficits in the realm of knowledge and the inability to harness local of knowledge of its relatively poor and uneducated population.

Again, megacities will continue to exert phenomenal impact on national and global economies. Traditionally, they are the economic nerve centres of their respective national economy and so are the nodes of international trade and economy. The effect of turn round time of ships and international containers are not solely contained by megacities or their host countries, they distribute globally. A cursory look at New York air traffic data shows an enormous 100 million passengers carried in 2005 alone. This exerts an additional burden on the already overstretched transport infrastructure in the megacity since a considerable number of these travellers will use the ground infrastructure. This trend obtains in Tokyo, Lagos and Mumbai being the major airports of their respective countries. Scarcely do megacities have adequate transport plan for these dynamic population.

\section{What are megacities' sustainable transport solutions?}

The transportation challenges for the sustainability of megacities could be achieved by the synergy of Demand sensitive, Environmentally friendly and Economically efficient transport system (DEE). To achieve this, megacities will need to reconsider their transport distribution strategy beginning from policy through planning to management taking into consideration their geographic and economic disposition.

Demand sensitivity: An effective transport system should basically meet the demand and supply needs of the city with minimal congestion. A detailed research will need to be done to establish congestion indices in cities and hence deduce what is tolerable.

Environmental friendliness: This is a crucial aspect of sustainable transport, having both social and economic dimensions. An environmentally friendly transport system will of necessity be flexible, offering a wide variety of attractive modal choices. It will be user-friendly offering as much information as necessarily. It will educate users on sustainability issues and attitudes so that users will make informed choices. It will have widely publicized safe practices and regulation so that users know their rights, limitations and liabilities. It should also spell out the responsibilities and liabilities of service providers and it should have a monitoring and evaluation responsibility as it operates within a very dynamic system. It considers impacts of transport on the environment in a holistic way and focuses on a balance of alternatives that gives the optimal 
service objective. In a way, it is the most challenging aspect of sustainable transport in megacities.

Economic efficiency: Balancing transport efficiency (matching demand with supply) with environmental friendliness is a very daunting and complex task requiring multiple factor considerations. This includes alternative funding costs and benefits analysis, appropriate transport pricing and investment strategies, sound economic appraisal of transport projects as well as good economic policies amongst others.

Globally, the level of knowledge and action linking megacity transport issues to sustainable development indices has been very low. It appears, however, that a new wind is now blowing and that initiatives such as the Sustainable Cities Programme by the UN New Partnership for African Development (NEPAD) will stimulate global think-tank towards sustainable megacity transport. Fortunately, Lagos is one of seven African cities chosen as being in need of urgent sustainability interventions. The developing world in particular, need not repeat the planning mistakes of the developed world but should evolve new strategies especially as megacities are increasingly turning to developing world phenomenon. It is hoped that the UN will work with Lagos address its megacity challenges.

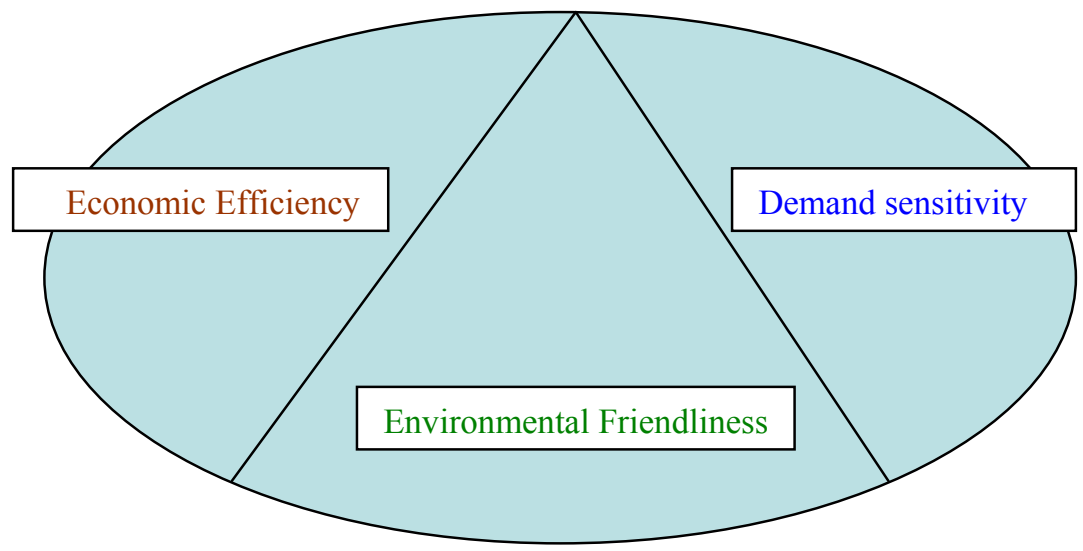

Figure 2: 'DEE' of Megacity sustainable transport.

\section{Conclusion}

Arguments in this paper have been chiefly those of scale and appropriate responses. Megacities do exhibit special transport problems which threatens both the immediate environment and global neighbourhood. They are virtually assuming country status with soaring population tending towards 30 million. It will therefore, be reasonable to have a rethink on the development strategies to 
cope with the current trends especially in the light of sustainable development. The following strategies are hereby recommended.

$>$ Megacity planning and management should come up on the international agenda and education research as an urgent priority.

$>$ Research funding for the purpose of finding alternative Best-Fit Transport Models to address sustainability in megacities is an urgent imperative.

$>$ System-wide and integrated policies and approaches should be encouraged as part of the new philosophy in megacity sustainable development.

$>$ Given the geographic configuration of megacities, the establishment of Megacities Transport Research Institutes in the applicable regions is highly recommended.

$>$ Sustainable Development education and sustainable megacity transport in particular should be embedded in our global academic and vocational curricula as a fundamental strategy towards sustainable development campaign.

\section{References}

[1] Banister, D., and Button, K. J. (1993), "Environmental Policy and Transport: An Overview" in Transport, Environment, and Sustainable Development, E.\& F. N., London, England

[2] Common Michael (1995), Sustainability and Policy: Limits to Economics. Cambridge University Press.

[3] Buck Nick et al. (Ed) (2005), Changing Cities - Rethinking Urban Competitiveness, Cohesion and Governance. Palgrave Macmillan. NY.

[4] Dwivedi et al. (1995), Bombay, The Cities Within. India Book House Pvt. Ltd. Hanson,

[5] Hanson Susan and Pratt Geraldine (Ed) 1995): The Geography of Urban Transportation (Second Edition). The Guilford Press. NY

[6] New York State Energy Research and Development Authority (NYSERDA).1999.Energy Programs for the Future: Entering the21st Century, 1999-2002 OECD (1992), Market Failures and the Environmental Management - The Case of Transport. OECD

[7] Rakodi, Carole (Ed) (1997): The Urban Challenge in Africa - Growth and Management of its large Cities. UN University Press, Tokyo.

[8] Texas Transport Institute (1999), Urban Mobility Study", Texas A \& M University, Texas.

[9] TRIP (2003), Analysis of U.S. Department of Transportation - Federal Highway Administration: Highway Statistics.

[10] UNCHS (Habitat) (2006): Cities in a Globalizing World - Global Report on Human Settlements 2001. Earthscan London.

[11] WHO/UNEP (1992): Urban Air Pollution in Megacities of the World. Blackwell Publishers, Oxford UK 
[12] Vasconcellos E.A (2001), Urban Transport, Environment \& Equity: The Case for developing Countries. Earthscan, London

[13] Zimmerman, R. 2001. "Social Implications of Infrastructure Network Interactions," Journal of Urban Technology, Vol. 8, No. 3, pp. 97-119.

[14] Defence, Carbon Emissions Fact Sheet, July 2002 http://www.tokyo-teleport.co.jp/english/tmg_991028/outline.html

[15] http://en.wikipedia.org/wiki/New_York_City, 2006

[16] http://wbln1018.worldbank.org/sar/sa.nsf/

[17] http://www.eia.doe.gov/oiaf/ieo/world.html

[18] http://www.guardian.co.uk/life/news/story/0,12976,1226074,00.html

[19] www.environmentaldefense.org/documents/2209

[20] http://www.globalpolicy.org/socecon/envronmt/transpt.htm

[21] http://www.worldwatch.org/pubs/sow/2004/

[22] http://www.oceanatlas.org/servlet/CDSServlet/

[23] http://www.earthscape.org/r1/ari01/aq11.html

[24] www.mlit.go.jp/road/road e/contents02/2-1-1.html

[25] http://www.wiaaindia.com/saferd.asp\#2

[26] www.milt.go.jp 